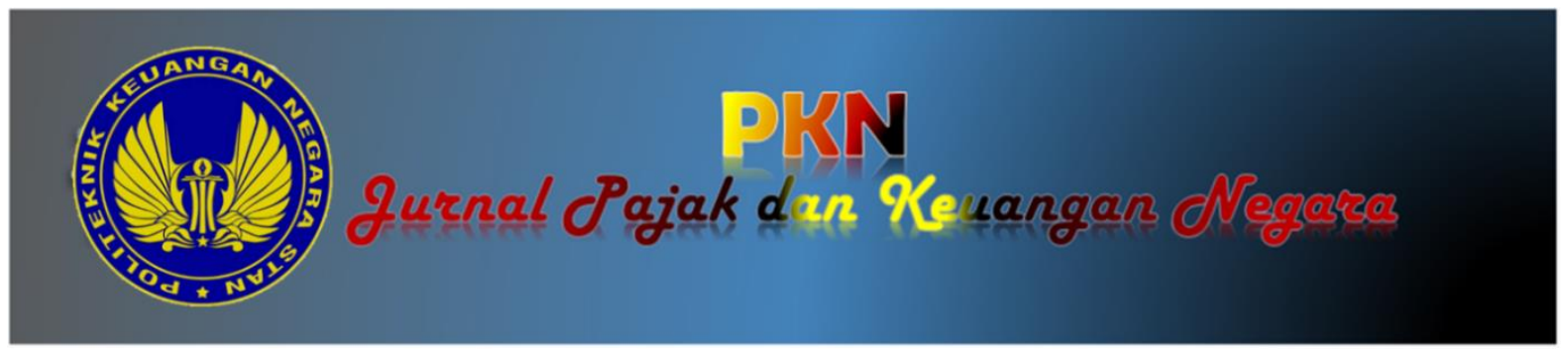

\title{
PENGARUH KEBIJAKAN INSENTIF PAJAK DI MASA PANDEMI COVID-19 TERHADAP PENERIMAAN PPN
}

\author{
Devi Nur Indahsari \\ Direktorat Jenderal Pajak \\ Alamat korespondensi: devifdg@gmail.com \\ Primandita Fitriandi \\ Politeknik Keuangan Negara STAN \\ Alamat korespondensi: primandita@pknstan.ac.id
}

INFORMASI ARTIKEL

Diterima Pertama

[28 04 2021]

Dinyatakan Diterima

[25 06 2021]

KATA KUNCI:

Insentif pajak, Pandemi, Penerimaan PPN.

KLASIFIKASI JEL:

$\mathrm{H} 210$

\section{ABSTRACT}

This study aims to analyze the effect of tax incentive during the Covid-19 pandemic on VAT revenues. The government hopes that tax incentives can increase people's purchasing power or consumption so that it has an impact on the objects of VAT imposition. This research is a causal assosiative-quantitative research. The results showed that tax incentives that had a significant effect on VAT revenues were income tax article 22 of import, income tax article 25, and final income tax PP 232018. The author hopes that this research can be used as an evaluation material for the implementation of tax incentive policies so that it can focus on incentives that are effective in increasing consumption and providing a large multiplier effect on the economy.

\section{ABSTRAK}

Penelitian ini bertujuan untuk menganalisis pengaruh insentif pajak di masa pandemi Covid-19 terhadap penerimaan PPN. Pemerintah berharap insentif pajak dapat meningkatkan daya beli atau konsumsi masyarakat sehingga berdampak terhadap objek pengenaan PPN. Penelitian ini merupakan penelitian kuantitatif-asosiatif kausal. Hasil penelitian menunjukkan bahwa insentif pajak yang berpengaruh signifikan terhadap penerimaan PPN adalah PPh Pasal 22 Impor, PPh Pasal 25, dan PPh final PP 23 tahun 2018. Penulis berharap penelitian ini dapat menjadi bahan evaluasi atas pelaksanaan kebijakan pemberian insentif pajak sehingga dapat fokus terhadap insentif yang efektif dalam meningkatkan konsumsi dan memberikan efek multiplier yang besar terhadap perekonomian. 


\section{PENDAHULUAN}

Sejak kemunculannya di akhir tahun 2019, wabah Covid-19 terus menunjukkan peningkatan di berbagai negara. Kebijakan pembatasan terhadap ruang gerak publik mau tidak mau terpaksa dilakukan oleh pemerintah seluruh dunia untuk menghambat penyebaran virus. Namun, kebijakan ini tentu berdampak buruk terhadap perekonomian secara global. Organization for Economic Co-Operation and Development (OECD) memprediksi bahwa dunia akan mengalami perlambatan ekonomi hingga menjadi yang terburuk sejak tahun 2009 (BBC News, 2020).

Pandemi Covid-19 telah mengakibatkan adanya perlambatan ekonomi bahkan mencapai angka minus. Data dari Badan Pusat Statistik menunjukkan bahwa komponen perekonomian pada tahun 2020 mengalami kontraksi sehingga produk domestik bruto cenderung menurun dibandingkan tahun 2019. Pertumbuhan ekonomi Indonesia juga mengalami perlambatan hingga mencapai $-5,32 \%$ pada kuartal kedua tahun 2020. Kontraksi paling dalam dialami oleh komponen konsumsi rumah tangga yang menjadi penopang paling dominan dalam produk domestik bruto. Secara matematis, produk domestik bruto $(\mathrm{Y})$ merupakan penjumlahan dari konsumsi (C), investasi (I), belanja pemerintah (G), dan net ekspor (X-M) (Dumairy, 2006). Dengan demikian, rendahnya konsumsi rumah tangga atau melemahnya daya beli masyarakat akan membawa dampak terhadap perekonomian secara keseluruhan.

Respon pemerintah dalam menanggapi rendahnya daya beli masyarakat diwujudkan melalui pemilihan opsi kebijakan fiskal yang ekspansif, salah satunya melalui penurunan tarif pajak. Tujuan kebijakan ini adalah menambah jumlah uang yang beredar sehingga masyarakat dapat membelanjakan uang lebih banyak dan merangsang pertumbuhan ekonomi (Priharto, 2018). Kebijakan pemberian insentif pajak merupakan salah satu opsi yang diambil pemerintah dalam bidang perpajakan. Secara sederhana, insentif pajak didefinisikan sebagai suatu fasilitas yang dialokasikan oleh pemerintah untuk individu atau organisasi tertentu demi memberikan kemudahan di bidang perpajakan sehingga mendorong wajib pajak patuh melaksanakan kewajiban perpajakannya (Dewi, 2019). Di masa pandemi Covid-19, pemerintah berharap insentif pajak dapat mendorong daya beli masyarakat yang terganggu dan cenderung menurun, membantu arus kas untuk aktivitas perusahaan, dan membantu pemenuhan kebutuhan impor atas bahan baku produksi (Akbar, 2021).

Dalam peraturan yang ditetapkan Maret 2020, pemerintah menerbitkan PMK Nomor 23/PMK.03/2020 tentang Insentif Pajak untuk Wajib Pajak Terdampak Wabah Virus Corona. PMK ini mengalami perubahan menjadi PMK Nomor 44/PMK.03/2020, selanjutnya diubah kembali menjadi PMK Nomor 86/PMK.03/2020, dan terakhir pada Agustus 2020 pemerintah menerbitkan PMK Nomor 110/PMK.03/2020. Penerbitan aturan-aturan ini merupakan upaya pemerintah untuk memberikan keringanan berupa pengurangan beban pajak, penurunan tarif, pembebasan pajak, dan relaksasi pelayanan perpajakan.

Berbagai jenis insentif pajak yang diberlakukan oleh pemerintah akan membawa dampak pada penerimaan pajak tahun 2020, khususnya penerimaan Pajak Pertambahan Nilai (PPN). Hal ini dikarenakan pemberian insentif pajak merupakan stimulus dari pemerintah untuk meningkatkan daya beli masyarakat atau konsumsi yang berdampak terhadap objek pengenaan PPN. Secara umum, penerimaan PPN dapat dikaitkan dengan daya beli masyarakat mengingat PPN merupakan pajak yang dikenakan atas konsumsi barang dan jasa (Hamid, 2019). Pertumbuhan penerimaan PPN selayaknya dapat menggambarkan peningkatan atau penurunan daya beli masyarakat.

Perubahan pola konsumsi akibat adanya insentif pajak juga dapat dikaitkan dengan produk domestik bruto (PDB). Peningkatan atau penurunan konsumsi (C) akan berdampak terhadap besarnya PDB dikarenakan konsumsi merupakan komponen terbesar penyusun PDB. Kepala Badan Pusat Statistik Suhariyanto (dalam Fitriani, 2020) menyatakan bahwa konsumsi rumah tangga memiliki kontribusi lebih dari lima puluh persen terhadap total produk domestik bruto. Sedangkan, PDB memiliki keterkaitan dengan PPN berdasarkan beberapa penelitian. Pengujian yang dilakukan oleh Herman (2007) menyatakan bahwa peningkatan PDB mampu meningkatkan penerimaan PPN. Selanjutnya, penelitian Masyitah (2019) menunjukkan hasil serupa yang menunjukkan bahwa PDB merupakan faktor yang berpengaruh signifikan terhadap penerimaan PPN dan PPnBM. Kedua hasil penelitian ini selaras dengan penelitian yang dilakukan oleh Velaj dan Prendi (2014), Tugino (2012), serta Saepudin (2008) yang memiliki kesimpulan serupa bahwa PDB mempunyai pengaruh signifikan terhadap penerimaan PPN. Dengan demikian, pemberian insentif pajak secara tidak langsung akan berdampak terhadap penerimaan PPN.

Berdasarkan fakta yang telah diuraikan, penelitian ini bertujuan untuk menganalisis pengaruh kebijakan pemberian insentif pajak terhadap penerimaan PPN. Insentif pajak yang akan diteliti pengaruhnya terdiri atas PPh Pasal 21 Ditanggung Pemerintah, pembebasan PPh Pasal 22 Impor, penurunan angsuran PPh Pasal 25, PPh final PP 23 tahun 2018 Ditanggung Pemerintah dan restitusi PPN dipercepat. Hasil penelitian ini diharapkan dapat 
memberikan kontribusi positif terhadap pengetahuan dan penelitian di bidang perpajakan, khususnya terkait kebijakan pemberian insentif pajak di masa pandemi.

\section{TINJAUAN PUSTAKA}

Pajak berperan penting dalam membangun tatanan perekonomian suatu negara. Di Indonesia, aktivitas perekonomian tidak terlepas dari fungsi pajak sebagai sumber pembiayaan negara. Penerimaan perpajakan menyumbang $83,5 \%$ dari total pendapatan negara berdasarkan Anggaran Pendapatan dan Belanja Negara (APBN) 2020. Kondisi ini menunjukkan pajak sebagai tulang punggung keuangan negara Indonesia. Kontribusinya yang begitu besar membuat pajak menjadi sumber pembiayaan untuk pengeluaran negara, termasuk dalam pelaksanaan pembangunan.

Secara umum, Waluyo (2013) dan Mardiasmo (2016) mengklasifikasikan pajak menjadi dua fungsi yaitu:

1) Fungsi Penerimaan atau Anggaran (Budgeter / Budgetair)

Menurut fungsi ini, pemerintah menggunakan pajak sebagai sumber pembiayaan atau sumber dana untuk membiayai seluruh pengeluaran.

2) Fungsi Mengatur (Regular / Regulerend)

Menurut fungsi ini, pemerintah menggunakan pajak sebagai alat untuk melaksanakan dan/atau mengatur berbagai kebijakan baik di bidang sosial maupun ekonomi.

Di masa pandemi Covid-19 dengan kondisi iklim ekonomi yang semakin tidak kondusif menuntut pemerintah mengeluarkan berbagai kebijakan di bidang perpajakan. Brzezinski (dalam Darussalam, 2020) mengungkapkan bahwa hukum pajak didesain untuk tunduk terhadap sasaran ekonomi. Artinya, pajak harus menyesuaikan diri dan memberi dukungan penuh terhadap kebijakan dan tujuan ekonomi. Mengutip dari Danny Darussalam Tax Center (DDTC) News, tujuan berbagai kebijakan perpajakan di masa pandemi adalah mencegah tingginya angka pengangguran, melindungi kestabilan investasi, menjaga cashflow sektor usaha, mendorong peningkatan konsumsi, dan sebagainya. Pemerintah Indonesia merespon kondisi lesunya perekonomian melalui penerbitan tujuh belas produk hukum perpajakan. Salah satu peraturan tersebut adalah Peraturan Menteri Keuangan Nomor 110/PMK.03/2020 tentang Insentif Pajak untuk Wajib Pajak Terdampak Pandemi Corona Virus Disease 2019. PMK terbaru yang ditetapkan bulan Agustus 2020 ini diundangkan untuk menyempurnakan halhal yang belum diatur pada peraturan sebelumnya.

Pada dasarnya, peraturan terkait insentif pajak telah muncul sejak terbitnya PMK Nomor
23/PMK.03/2020. PMK ini kemudian berubah menjadi PMK Nomor 44/PMK.03/2020 dengan menambahkan insentif pajak penghasilan final. Selanjutnya, pada PMK Nomor 86/PMK.03/2020 dilakukan perluasan terhadap Klasifikasi Lapangan Usaha (KLU) pajak dan memperpanjang diberlakukannya insentif pajak. Berdasarkan PMK ini, insentif pajak dapat dimanfaatkan hingga akhir Desember 2020. Kemudian, pemerintah menerbitkan PMK Nomor 110/PMK.03/2020 dengan menambahkan insentif PPh final jasa konstruksi ditanggung pemerintah dan menaikkan pengurangan angsuran PPh Pasal 25.

Barry (dalam Maulinarhadi dan Agusti, 2019) menjelaskan bahwa insentif pajak merupakan suatu bentuk keringanan atau fasilitas dari pemerintah yang dialokasikan kepada wajib pajak tertentu berupa penurunan tarif pajak yang memiliki tujuan untuk mengurangi besarnya beban pajak yang harus disetorkan kepada pemerintah. Contoh insentif pajak antara lain: (1) pengecualian atas pengenaan pajak, (2) penangguhan pajak, (3) pengurangan dasar pengenaan pajak, dan (4) penurunan tarif pajak. Insentif pajak juga dapat didefinisikan sebagai suatu fasilitas yang dialokasikan oleh pemerintah untuk individu atau organisasi tertentu demi memberikan kemudahan di bidang perpajakan sehingga mendorong wajib pajak patuh melaksanakan kewajiban perpajakannya (Dewi, 2019).

Insentif pajak kerap digunakan sebagai instrumen kebijakan yang digunakan oleh pemerintah suatu negara demi menarik minat para investor dalam berinvestasi. Perserikatan BangsaBangsa (dalam Trepelkov et al, 2017) menjelaskan bahwa insentif pajak ialah tentang kompetisi pajak di mana suatu negara bersaing untuk memperoleh investasi sehingga investor tidak pindah ke lain negara. Pada lingkup yang lebih luas, insentif pajak dapat digunakan untuk memengaruhi kegiatan perekonomian yang mungkin sedang lesu. Hal ini selaras dengan yang disampaikan oleh Gunadi (2013) bahwa insentif pajak mampu menurunkan biaya pajak dibandingkan negara lain sehingga memungkinkan investor tertarik untuk menanamkan modal. Dengan demikian, produktivitas nasional akan meningkat dan memberikan tambahan penghasilan pada masyarakat sehingga produk domestik bruto dan kesejahteraan masyarakat meningkat.

Di masa pandemi Covid-19, kebijakan pemberian insentif pajak digunakan untuk menanggapi krisis yang muncul sebagaimana penelitian yang dilakukan oleh Padyanoor (2020) dengan menitikberatkan pada manfaat bagi para wajib pajak. Hasil penelitian menyatakan bahwa kebijakan insentif pajak berupa penurunan tarif hingga pembebasan atas pajak bermanfaat untuk memberikan tambahan penghasilan dan tambahan 
modal yang dapat digunakan oleh wajib pajak sehingga mempercepat penanganan dampak dari Covid-19. Selanjutnya, Kumar dan Aribowo (2020) dalam penelitiannya menyatakan bahwa pemberian insentif fiskal memberikan tambahan penghasilan yang mampu mempertahankan daya beli dan tingkat konsumsi masyarakat. Konsumsi ini memberikan efek multiplier yang menimbulkan objek PPN pada setiap rantai konsumsi yang dilakukan sehingga penerimaan pajak tetap terjaga. Hal serupa ditunjukkan pada hasil penelitian Utami (2010) yang menguji pengaruh insentif PPh Pasal 21 sebagai salah satu kebijakan yang dilakukan oleh pemerintah. Penelitian menunjukkan bahwa insentif PPh Pasal 21 berdampak positif bagi pekerja berupa peningkatan daya beli, peningkatan pendapatan pekerja, peningkatan kesadaran terhadap mekanisme perpajakan, dan menurunkan angka pengangguran akibat adanya Pemutusan Hubungan Kerja (PHK).

Kebijakan pemberian insentif pajak merupakan stimulus dari pemerintah untuk meningkatkan daya beli masyarakat atau konsumsi yang berdampak terhadap objek pengenaan PPN. Secara umum, daya beli masyarakat dapat dikaitkan dengan penerimaan PPN mengingat PPN merupakan pajak yang dikenakan atas konsumsi barang dan jasa (Hamid, 2019). Pertumbuhan penerimaan PPN selayaknya dapat menggambarkan peningkatan atau penurunan daya beli masyarakat. Selain itu, perubahan pola konsumsi akibat adanya insentif pajak juga dapat dikaitkan dengan produk domestik bruto (PDB). Peningkatan atau penurunan konsumsi (C) akan berdampak terhadap besarnya PDB dikarenakan konsumsi merupakan komponen terbesar penyusun PDB. Sedangkan, PDB memiliki keterkaitan dengan PPN berdasarkan beberapa penelitian. Pengujian yang dilakukan oleh Herman (2007), Masyitah (2019, Velaj dan Prendi (2014), Tugino (2012), serta Saepudin (2008) memiliki kesimpulan serupa bahwa PDB mempunyai pengaruh signifikan terhadap penerimaan PPN. Dengan demikian, pemberian insentif pajak secara tidak langsung akan berdampak terhadap penerimaan PPN.

\section{METODE PENELITIAN}

Penelitian ini merupakan penelitian asosiatif yang berfungsi untuk menjelaskan atau meramalkan hubungan antara insentif pajak sebagai variabel independen terhadap variabel dependen berupa penerimaan PPN. Teknik yang digunakan adalah teknik analisis statistik atau dikenal sebagai teknik kuantitatif. Teknik kuantitatif merupakan penelitian yang lebih didominasi oleh penggunaan angka, mulai dari tahapan pengumpulan data, penafsiran data, hingga hasil pengolahan data (Arikunto, 2006).
Penelitian ini menggunakan data sekunder yang diperoleh dari bidang Data dan Pengawasan Potensi Perpajakan (DP3) Kanwil DJP Jawa Tengah I. Populasi yang digunakan dalam penelitian meliputi seluruh wajib pajak terdaftar di 17 KPP yang termasuk dalam wilayah kerja Kantor Wilayah DJP Jawa Tengah I. Penelitian ini menggunakan seluruh populasi sebagai sampel penelitian. Berdasarkan data yang diperoleh, penulis menggunakan software STATA 14.2 untuk melakukan pengolahan data panel. Secara umum, analisis data dimulai dengan tahapan input dataset ke memori, mengolah data dengan serangkaian perintah (command), hingga menampilkan dan menyimpan output.

Penelitian ini dibangun berdasarkan kerangka pemikiran dengan menggunakan tiga jenis variabel. Pertama, variabel independen berupa insentif pajak yang terdiri dari insentif PPh Pasal 21, insentif PPh Pasal 22 Impor, insentif PPh Pasal 25, insentif PPh final berdasarkan Peraturan Pemerintah Nomor 23 Tahun 2018, dan insentif PPN. Kedua, penulis menggunakan variabel kontrol berupa jumlah Pengusaha Kena Pajak (PKP). Ketiga, variabel dependen yang akan dilihat pengaruhnya adalah penerimaan PPN. Berikut merupakan kerangka pemikiran penelitian yang digunakan oleh penulis.

Gambar 3.1

Kerangka Konseptual Penelitian

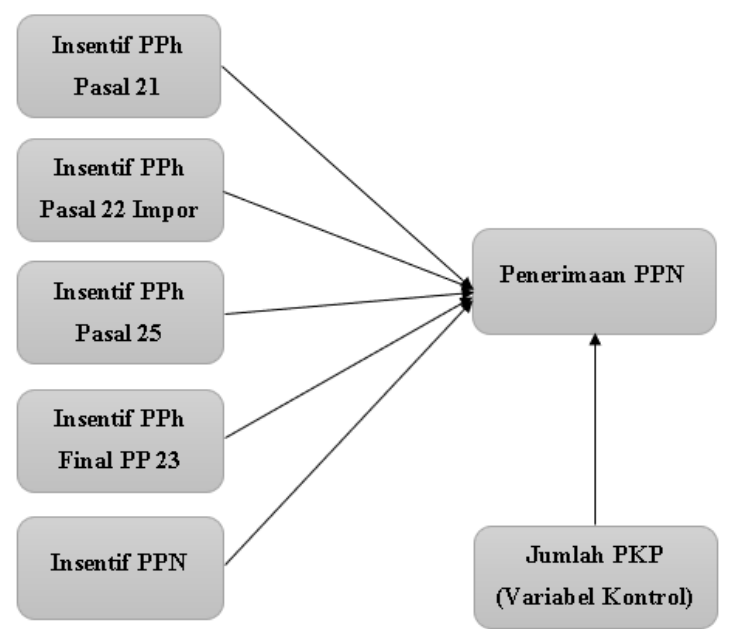

Sumber: Hasil olah penulis

Adapun model penelitian ditampilkan sebagai berikut.

$$
\begin{aligned}
& \text { PPN }_{\text {it }}=\beta_{0 \text { it }}+\beta_{1} \text { IP21 }_{\text {it }}+\beta_{2} \text { IP22 }_{\text {it }} \\
& +\beta_{3} \text { IP25 }_{\text {it }}+\beta_{4} \text { IPF }_{\text {it }} \\
& +\beta_{5} \text { IPN }_{i t}+\beta_{6} \text { PKP }_{i t}+\varepsilon_{i t}
\end{aligned}
$$

Keterangan:

PPN : Penerimaan PPN

IP21 :Insentif PPh Pasal 21

IP22 : Insentif PPh Pasal 22 Impor

IP25 : Insentif angsuran PPh Pasal 25

IPF : : :nsentif PPh final PP 23 Tahun 2018

IPN : Insentif PPN 


\begin{tabular}{ll}
\hline PKP & : Jumlah PKP \\
$\varepsilon$ & $:$ Error term \\
$\mathrm{i}$ & $:$ Kantor Pelayanan Pajak (KPP) \\
$\mathrm{t}$ & $:$ Masa Pajak \\
& Variabel dependen yang digunakan
\end{tabular}
merupakan realisasi penerimaan PPN selama enam bulan yaitu masa pajak April hingga Desember 2020 pada 17 KPP di lingkungan Kanwil DJP Jawa Tengah I. Realisasi tersebut meliputi seluruh penerimaan pajak atas konsumsi barang dan/atau jasa di dalam daerah pabean yang dikenakan tarif bertingkat pada setiap rantai produksi dan distribusi. Data penerimaan PPN yang digunakan terdiri atas PPN Dalam Negeri (411211), PPN Impor (411212), dan PPN Lainnya (411219). Realisasi penerimaan PPN meliputi setiap rupiah PPN yang disetorkan oleh wajib pajak ke kas negara dan menjadi hak milik negara. Secara sederhana, penghitungan PPN dilakukan dengan mengkreditkan atau mengurangkan pajak masukan terhadap pajak keluaran di dalam masa pajak yang sama. Dengan demikian, realisasi penerimaan PPN dapat bernilai positif ataupun negatif.

Sedangkan, variabel independen berupa insentif pajak yang digunakan dalam penelitian merupakan realisasi penyerapan insentif dalam rentang enam bulan dengan satuan nilai rupiah. Data yang digunakan terdiri dari:

a. Insentif PPh Pasal 21

Semula, atas penghasilan yang diperoleh pegawai dengan kriteria sebagaimana dimaksud dalam PMK Nomor 86/PMK.03/2020 akan dikenakan PPh Pasal 21 setiap bulan oleh pemberi kerja sesuai tarif pasal 17 ayat (1) huruf a Undang-Undang PPh. Dengan adanya insentif, pemerintah akan menanggung PPh Pasal 21 yang semula dikenakan terhadap wajib pajak. Data insentif PPh Pasal 21 yang digunakan meliputi seluruh realisasi penyerapan insentif PPh Pasal 21 yang dimanfaatkan oleh wajib pajak pada masa pajak tertentu. Insentif PPh Pasal 21 dapat diukur melalui jumlah yang seharusnya dibayarkan oleh pemberi kerja pada saat pembayaran penghasilan kepada pegawai, termasuk ketika pemberi kerja memberikan tunjangan PPh Pasal 21 atau menanggung PPh Pasal 21 kepada pegawai.

b. Insentif PPh Pasal 22 Impor

Insentif PPh Pasal 22 Impor merupakan pembebasan pemungutan kepada wajib pajak yang berkaitan dengan pembayaran atas penyerahan barang dan/atau kegiatan di bidang impor atau kegiatan usaha di bidang lain. Data insentif PPh Pasal 22 Impor yang digunakan meliputi seluruh realisasi penyerapan insentif PPh Pasal 22 Impor yang dimanfaatkan oleh wajib pajak pada masa pajak tertentu. Realisasi ini diukur berdasarkan nominal yang tertera dalam Surat Keterangan Bebas (SKB) yang telah disetujui oleh Kepala KPP di lingkungan kerja Kanwil DJP Jawa Tengah I sejak tanggal diterbitkan hingga akhir Desember 2020. Dengan demikian, permohonan SKB yang tidak diterima atau diterbitkan surat penolakan tidak termasuk ke dalam realisasi insentif PPh Pasal 22 Impor.

c. Insentif PPh Pasal 25 Insentif PPh Pasal 25 diberikan dalam bentuk pengurangan terhadap besarnya angsuran PPh Pasal 25 dalam tahun pajak berjalan yang masih harus dibayarkan oleh wajib pajak setiap bulan. Realisasi insentif PPh Pasal 25 yang digunakan meliputi seluruh realisasi penyerapan insentif angsuran PPh Pasal 25 yang dimanfaatkan oleh wajib pajak yang termasuk Klasifikasi Lapangan Usaha (KLU) tertentu. PMK Nomor 23/PMK.03/2020 telah mengatur bahwa angsuran PPh Pasal 25 mendapatkan pengurangan sebesar $30 \%$, yang kemudian diberikan tambahan pengurangan menjadi $50 \%$ sejak diterbitkannya PMK Nomor 110/PMK.03/2020. Dengan demikian, insentif angsuran PPh Pasal 25 terdiri dari dua tarif yaitu: (1) Tarif pengurangan 30\% atas angsuran PPh Pasal 25 berlaku pada masa pajak April hingga Juni 2020; dan (2) Tarif pengurangan 50\% atas angsuran PPh Pasal 25 berlaku pada masa pajak Juli hingga Desember 2020.

d. Insentif PPh Final Berdasarkan Peraturan Pemerintah Nomor 23 Tahun Insentif PPh final ini adalah jenis insentif pajak yang ditujukan atas penghasilan dari usaha yang diterima atau diperoleh wajib pajak UMKM dengan peredaran bruto tertentu sebagaimana diatur dalam Peraturan Pemerintah Nomor 23 Tahun 2018. Dengan adanya insentif, PPh final yang semula dikenakan tarif 0,5\% kini menjadi ditanggung pemerintah sejak masa pajak April hingga Desember 2020. Data insentif PPh final yang digunakan dalam penelitian meliputi seluruh realisasi penyerapan insentif PPh final yang dimanfaatkan oleh wajib pajak yang telah mengajukan permohonan Surat Keterangan untuk memperoleh insentif. Realisasi ini diukur berdasarkan laporan realisasi PPh final Ditanggung Pemerintah yang wajib dilaporkan sebagaimana diatur dalam PMK Nomor 86/PMK.03/2020.

e. Insentif PPN

Insentif PPN merupakan fasilitas berupa pengembalian pendahuluan kelebihan pembayaran pajak sebagai PKP berisiko rendah sebagaimana dimaksud dalam Pasal 9 ayat (4c) UndangUndang PPN yang ditujukan terhadap wajib pajak yang telah menyampaikan SPT Masa PPN lebih bayar restitusi dengan nilai maksimal 
lima miliar rupiah. Data insentif PPN yang digunakan dalam penelitian meliputi seluruh realisasi penyerapan insentif PPN yang dimanfaatkan oleh wajib pajak tanpa perlu melakukan permohonan penetapan sebagai PKP berisiko rendah. Realisasi ini diukur berdasarkan jumlah lebih bayar PPN pada masa pajak tertentu, termasuk kompensasi atas kelebihan pajak dari masa sebelumnya yang turut diperhitungkan dalam SPT Masa PPN yang dimintakan pengembalian pendahuluan.

\section{HASIL PENELITIAN}

\subsection{Analisis Deskriptif}

Berikut merupakan analisis deskriptif atas data yang diperoleh.

Tabel IV.1

Statistik Deskriptif Variabel Penelitian

\begin{tabular}{|l|c|c|c|}
\hline & $\underline{\underline{\text { P21 }}}$ & $\underline{\underline{\mathbf{I P 2 2}}}$ & $\underline{\underline{\mathbf{I P 2 5}}}$ \\
\hline Mean & 441.280 .278 & 869.496 .340 & 2.575 .226 .516 \\
\hline Median & 382.158 .919 & 296.239 .972 & 609.697 .218 \\
\hline $\begin{array}{l}\text { Standard } \\
\text { Deviation }\end{array}$ & 280.948 .845 & 1.799 .341 .505 & 8.365 .772 .658 \\
\hline Minimum & 95.783 .020 & 0 & 159.103 .239 \\
\hline Maximum & 1.279 .380 .152 & 10.713 .086 .131 & 50.632 .577 .562 \\
\hline Count & 102 & 102 & 102 \\
\hline & $\underline{\mathbf{I P F}}$ & $\underline{\underline{\mathbf{P N}}}$ & $\underline{\mathbf{P P N}}$ \\
\hline Mean & 244.037 .373 & 1.963 .892 .554 & 55.425 .173 .777 \\
\hline Median & 212.160 .980 & 917.375 .425 & 16.602 .719 .539 \\
\hline $\begin{array}{l}\text { Standard } \\
\text { Deviation }\end{array}$ & 150.176 .156 & 2.822 .504 .880 & 174.019 .597 .359 \\
\hline Minimum & 0 & 0 & -212.716 .656 .093 \\
\hline Maximum & 742.033 .471 & 14.752 .101815 & 1.110 .506 .834 .937 \\
\hline Count & 102 & 102 & 102 \\
\hline
\end{tabular}

Sumber : Hasil olah penulis dari data sekunder

\subsection{Analisis Regresi}

\subsubsection{Winsorizing}

Sebelum mengidentifikasi model regresi yang paling sesuai, penulis melakukan tahapan winsorizing terhadap data penelitian. Winsorizing merupakan salah satu cara yang dapat digunakan untuk mengatasi data yang nilainya ekstrim, di samping transforming dan treammean (Ghozali, 2011). Dalam penelitian ini, winsorize memiliki dua fungsi utama. Pertama, winsorize digunakan untuk meminimalisir adanya data outlier yang memungkinkan analisis terhadap data menjadi bias. Kedua, winsorize berfungsi untuk menangani variasi data yang terlalu tinggi. Winsorize yang digunakan dalam penelitian ini merupakan winsorize 95\%, artinya 2,5\% dari nilai terendah dan nilai tertinggi dari seluruh data akan dikodekan ulang ke dalam suatu data baru.

\subsubsection{Pemilihan Model Regresi}

Setelah melakukan winsorizing 95\% terhadap seluruh variabel penelitian, selanjutnya data diolah untuk mengidentifikasi model estimasi yang paling sesuai. Pengidentifikasian model dilakukan dengan beberapa tahapan pengujian yaitu uji Chow, uji Hausman, dan uji Breusch-Pagan Lagrange Multiplier. Berdasarkan ketiga pengujian diperoleh hasil bahwa model yang terpilih adalah Random Effect Model.

Tabel IV.2

Hasil Uji Pemilihan Model Regresi

\begin{tabular}{|l|c|c|c|}
\hline \multicolumn{1}{|c|}{ Uji Penentuan Model } & CEM & FEM & REM \\
\hline $\mathrm{U}_{\mathrm{ji} \text { Chow }}$ & $\mathrm{x}$ & $\sqrt{ }$ & \\
\hline $\mathrm{U}_{\mathrm{ji} \text { Hausman }}$ & & $\mathrm{x}$ & $\sqrt{ }$ \\
\hline $\mathrm{U}_{\mathrm{ji} \text { Breusch-Pagan Lagrange Multiplier }}$ & $\mathrm{x}$ & & $\sqrt{ }$ \\
\hline \multicolumn{2}{|c|}{ Model Terpilih } & $\sqrt{ }$ \\
\hline
\end{tabular}

Sumber : Hasil olah penulis

\subsubsection{Uji Asumsi Klasik}

Dengan Random Effect Model sebagai model terpilih maka uji asumsi klasik dilakukan dengan pendekatan Generalized Least Squared. Uji asumsi klasik yang dilakukan meliputi uji multikolinearitas, uji autokorelasi, dan uji normalitas. Uji heteroskedastisitas tidak perlu dilakukan karena Generalized Least Squared dapat digunakan untuk menanggulangi masalah heteroskedastisitas (Greene, 1997).

\subsubsection{Uji Multikolinearitas}

Dalam penelitian ini, penulis mendeteksi ada atau tidaknya multikolonearitas dengan cara menghitung koefisien korelasi antar variabel independen. Hasil pengujian menunjukkan bahwa antar variabel independen memiliki koefisien korelasi dengan nilai kurang dari 0,90. Artinya, antar variabel independen tidak memiliki korelasi satu dengan yang lain sehingga model regresi bebas dari masalah multikolinearitas.

Gambar IV.1

Hasil Uji Multikolinearitas

\begin{tabular}{|r|rrrrrr|} 
& & & & \\
& (obs $=102)$ & & & & \\
& & & & & \\
& & & & \\
& & & & \\
IP21_95 & $\mathbf{1 . 0 0 0 0}$ & & & & & \\
IP22_95 & $\mathbf{0 . 2 4 0 4}$ & $\mathbf{1 . 0 0 0 0}$ & & & & \\
IP25_95 & $\mathbf{0 . 2 8 8 1}$ & $\mathbf{0 . 7 9 2 3}$ & $\mathbf{1 . 0 0 0 0}$ & & & \\
IPF_95 & $\mathbf{0 . 3 5 9 6}$ & $\mathbf{- 0 . 2 4 1 8}$ & $\mathbf{- 0 . 2 7 4 3}$ & $\mathbf{1 . 0 0 0 0}$ & & \\
IPN_95 & $\mathbf{0 . 3 0 7 7}$ & $\mathbf{0 . 4 4 4 1}$ & $\mathbf{0 . 5 2 7 2}$ & $\mathbf{0 . 0 7 8 9}$ & $\mathbf{1 . 0 0 0 0}$ & \\
PKP_95 & $\mathbf{0 . 1 8 4 8}$ & $-\mathbf{0 . 1 6 4 2}$ & $-\mathbf{0 . 2 7 2 7}$ & $\mathbf{0 . 7 8 3 9}$ & $\mathbf{0 . 1 2 0 4}$ & $\mathbf{1 . 0 0 0 0}$ \\
\hline
\end{tabular}

Sumber : Output STATA 14.2

\subsubsection{Uji Autokorelasi}

Dalam data panel dengan Random Effect Model sebagai model terpilih, uji autokorelasi merupakan pengujian yang opsional dan tidak harus dilakukan (Mardani, 2020). Uji autokorelasi dilakukan dengan membandingkan nilai Prob > $F$ yang dihasilkan STATA dengan nilai signifikansi (alpha). Penulis menggunakan besaran nilai alpha $(\alpha)$ sebesar 0,05 , artinya tingkat keyakinan yang dikehendaki sebesar 5\%. Berdasarkan hasil pengujian, nilai Prob > $\mathrm{F}$ menunjukkan angka 0,0508 atau lebih dari nilai signifikansi 0,05 . Artinya, hipotesis nul $\left(\mathrm{H}_{0}\right)$ gagal 
ditolak sehingga tidak terdapat masalah autokorelasi dalam model penelitian.

\subsubsection{Uji Normalitas}

Dalam penelitian ini, penulis melakukan uji normalitas dengan dua cara yaitu analisis statistik dan non statistik. Metode statistik dilakukan dengan Skewness and Kurtosis Test for Normality yang dilakukan dengan membandingkan nilai probabilitas chi square yang dihasilkan STATA dengan tingkat signifikansi $(\alpha)$ sebesar 0,05 . Berdasarkan hasil pengujian, nilai probabilitas chi square (Prob>chi2) menunjukkan angka 0,000 atau lebih kecil dari tingkat signifikansi 0,05 . Artinya, hipotesis nul $\left(\mathrm{H}_{0}\right)$ ditolak sehingga data tidak terdistribusi normal.

Selain menggunakan analisis statistik, penulis menguji normalitas data dengan analisis grafik. Model regresi dianggap memenuhi asumsi normalitas jika grafik menggambarkan data dengan titik yang tersebar di sekitar garis diagonal dan mengikuti arah garis diagonal tersebut. Hasil uji normalitas yang dipaparkan dalam grafik di atas menunjukkan bahwa cerminan data berupa titik data yang menyebar jauh dari garis diagonal dan penyebarannya tidak searah mengikuti grafik diagonal. Dengan demikian, dapat ditarik kesimpulan bahwa data sampel yang digunakan tidak terdistribusi secara normal. Adapun hasil uji normalitas dengan menggunakan grafik ditampilkan sebagai berikut.

Gambar IV.1 Hasil Uji Normalitas Grafik

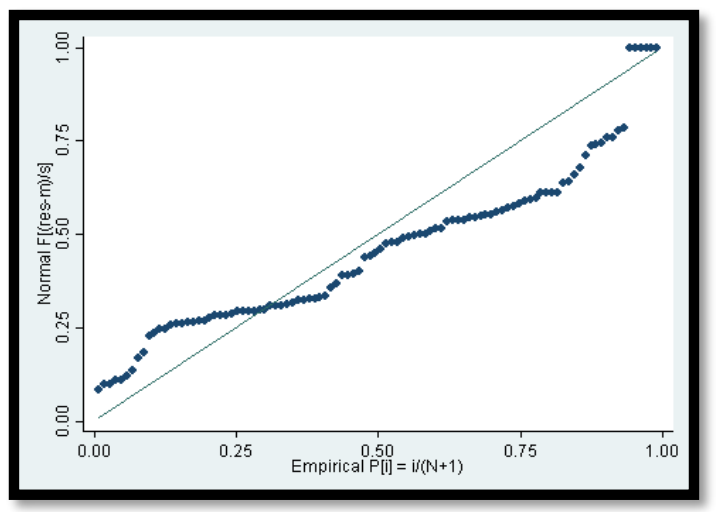

Sumber: Output STATA 14.2

Pada dasarnya, uji normalitas tidak termasuk syarat BLUE (Best Linier Unbias Estimator). Hasil uji normalitas dalam penelitian ini menggunakan teori yang disebut Central Limited Theorma (CLT) yang menyatakan bahwa data dianggap telah terdistribusi secara normal apabila memiliki jumlah sampel penelitian yang besar dalam penelitian. Menurut Ghozali (2005), dalil Central Limited Theorma mengasumsikan data akan terdistribusi normal jika jumlah sampel lebih besar dari 30. Pendapat lain disampaikan bahwa batas jumlah pengamatan dikategorikan dalam jumlah besar jika memiliki jumlah pengamatan (n) di atas 100
(Gujarati dan Porter, 2009). Penulis menggunakan data observasi sebesar 102 data, artinya berdasarkan asumsi CLT maka data yang ada telah memenuhi asumsi normalitas meskipun hasil pengujian baik statistik maupun grafik menunjukkan bahwa data tidak berdistribusi normal.

\subsubsection{Uji Regresi Data Panel}

\subsubsection{Analisis Regresi Linier Berganda}

Setelah melakukan analisis regresi Random Effect Model (REM) dengan menggunakan STATA 14.2, maka diperoleh persamaan regresi penerimaan PPN sebagai berikut.

$$
\begin{aligned}
\text { PPN }_{\text {it }}= & 4,6910+25,46736 \mathrm{IP21}_{\mathrm{it}} \\
& +10,45746 \mathrm{IP22}_{\mathrm{it}} \\
& +12,1644 \mathrm{IP}_{\mathrm{it}} \\
& -77,21915 \mathrm{IPF}_{\mathrm{it}} \\
& +1,99238 \mathrm{IPN}_{\mathrm{it}} \\
& -1,6407 \mathrm{PKP}_{\mathrm{it}}+\varepsilon
\end{aligned}
$$

\subsubsection{Analisis Koefisien Determinasi}

Nilai $R$-squared overall dalam penelitian ini adalah 0,7444 , artinya variasi nilai penerimaan PPN mampu dijabarkan oleh variabel bebas dalam model penelitian sebesar $74,44 \%$. Analisis koefisien determinasi memiliki kelemahan yaitu dengan menggunakan $R$-squared dinilai memiliki sifat bias terhadap jumlah variabel independen yang dimasukan dalam model (Ghozali, 2016). Nilai yang lebih tepat digunakan untuk mengevaluasi model regresi adalah nilai adjusted $R$-squared di mana nilai ini akan naik atau turun seiring dengan adanya penambahan variabel independen baru. Berdasarkan pengolahan diperoleh nilai adjusted $R$-squared sebesar 0,7282 . Nilai ini menunjukkan bahwa variasi nilai penerimaan PPN dapat dijelaskan oleh variabel independen dalam model penelitian sebesar $72,82 \%$. Sedangkan, sisanya sebesar $27,18 \%$ dijelaskan oleh faktor-faktor lain di luar model penelitian.

\subsubsection{Uji F (Uji Signifikansi Simultan)}

Uji F dilakukan dengan membandingkan nilai Prob > F yang dihasilkan STATA dengan tingkat signifikansi (alpha) sebesar 0,05. Berdasarkan hasil pengujian, nilai Prob > F menunjukkan angka 0,000 atau lebih kecil dari tingkat signifikansi 0,05. Artinya, hipotesis nul $\left(\mathrm{H}_{0}\right)$ ditolak sehingga seluruh variabel independen secara bersama-sama atau simultan memiliki pengaruh terhadap variabel dependen.

\subsubsection{Uji t (Uji Signifikansi Parsial)}

Pengujian dilakukan dengan mengamati nilai $\mathrm{P}>|\mathrm{z}|$ pada setiap variabel independen untuk selanjutnya dibandingkan dengan tingkat signifikansi (alpha). 


\begin{tabular}{|c|c|c|c|c|c|c|}
\hline \multicolumn{7}{|c|}{$\begin{array}{c}\text { Gambar IV.2 } \\
\text { Hasil Ujit }\end{array}$} \\
\hline PPN_95 & coet. & std. $\mathrm{Brr}$ & $\mathrm{z}$ & $p>|z|$ & 1954 cont. & . Interval1 \\
\hline IP21_95 & 25.46736 & 24.41139 & 1.04 & 0.297 & -22.37809 & 73. 31281 \\
\hline IP22_95 & 10.45746 & 4. 079583 & 2.56 & 0.010 & 2.461622 & 18.45329 \\
\hline IP25_95 & $\begin{array}{r}12.1644 \\
\end{array}$ & $\begin{array}{l}2.0133854 \\
.14874\end{array}$ & 3.87 & 0.000 & 6.002525 & 18.32628 \\
\hline $\begin{array}{l}\text { IPF } 95 \\
\text { IPS }\end{array}$ & -77.21915 & 35.76665 & -2.16 & 0.031 & -147.3205 & $\begin{array}{r}-7.117812 \\
\end{array}$ \\
\hline IPN-95 & 1.99238 & 1.263836 & 1.58 & 0.115 & -.4846929 & 4.469454 \\
\hline PKP_-95 & $-1.64 \mathrm{e}+07$ & $1.18 e+07$ & -1.39 & 0.165 & $-3.94 e+07$ & 6708435 \\
\hline _cons & $4.69 \mathrm{e}+10$ & $2.16 \mathrm{e}+10$ & 2.17 & 0.030 & 4. $60 e+09$ & 8. $93 \mathrm{e}+10$ \\
\hline sigma_u & 2. $932 \mathrm{e}+10$ & & & & & \\
\hline $\begin{array}{l}\text { si grma_o } \\
\text { rho }\end{array}$ & $\begin{array}{r}9.9580+09 \\
.89659736\end{array}$ & (fraction & rax & due & ou_it & \\
\hline
\end{tabular}

Sumber : Output STATA 14.2

Hasil uji t menunjukkan bahwa hipotesis dua, tiga, dan empat diterima, sedangkan hipotesis pertama dan kelima ditolak. Adapun pengaruh masing-masing variabel independen secara parsial terhadap variabel dependen berdasarkan hasil uji $t$ dijelaskan sebagai berikut.

a. Variabel insentif PPh Pasal 21 memiliki nilai $\mathrm{P}>|\mathrm{z}|$ sebesar 0,297 . Nilai probabilitas ini lebih besar dibandingkan tingkat signifikansi 0,05 sehingga hipotesis nul $\left(\mathrm{H}_{0}\right)$ gagal ditolak. Dengan demikian, kebijakan pemberian insentif PPh Pasal 21 di masa pandemi Covid-19 tidak berpengaruh signifikan terhadap penerimaan PPN pada tingkat keyakinan 95\%.

b. Variabel insentif PPh Pasal 22 Impor memiliki nilai $P>|z|$ sebesar 0,010 . Nilai probabilitas ini lebih kecil dibandingkan tingkat signifikansi 0,05 sehingga hipotesis nul $\left(\mathrm{H}_{0}\right)$ ditolak. Dengan demikian, kebijakan pemberian insentif PPh Pasal 22 Impor di masa pandemi Covid-19 berpengaruh signifikan secara positif terhadap penerimaan PPN pada tingkat keyakinan $95 \%$.

c. Variabel insentif PPh Pasal 25 memiliki nilai $P>|z|$ sebesar 0,000 . Nilai probabilitas ini lebih kecil dibandingkan tingkat signifikansi 0,05 sehingga hipotesis nul $\left(\mathrm{H}_{0}\right)$ ditolak. Dengan demikian, kebijakan pemberian insentif PPh Pasal 25 di masa pandemi Covid-19 berpengaruh signifikan secara positif terhadap penerimaan PPN pada tingkat keyakinan 95\%.

d. Variabel insentif PPh Final berdasarkan PP Nomor 23 Tahun 2018 memiliki nilai $P>|z|$ sebesar 0,031. Nilai probabilitas ini lebih kecil dibandingkan tingkat signifikansi 0,05 sehingga hipotesis nul $\left(\mathrm{H}_{0}\right)$ ditolak. Dengan demikian, kebijakan pemberian insentif PPh Final berdasarkan PP Nomor 23 Tahun 2018 di masa pandemi Covid-19 berpengaruh signifikan secara negatif terhadap penerimaan PPN pada tingkat keyakinan 95\%.

e. Variabel insentif PPN memiliki nilai $P>|z|$ sebesar 0,115 . Nilai probabilitas ini lebih besar dibandingkan tingkat signifikansi 0,05 sehingga hipotesis nul $\left(\mathrm{H}_{0}\right)$ gagal ditolak. Dengan demikian, kebijakan pemberian insentif PPN di masa pandemi Covid-19 tidak berpengaruh signifikan terhadap penerimaan PPN pada tingkat

keyakinan $95 \%$.

\subsection{Pembahasan}

\subsubsection{Pengaruh Insentif PPh Pasal 21 Terhadap Penerimaan PPN}

Hasil pengujian yang telah dilakukan menunjukkan bahwa insentif PPh Pasal 21 tidak berpengaruh secara signifikan terhadap penerimaan PPN. Penelitian ini menampilkan hasil yang sejalan dengan apa yang disampaikan oleh Hartini (2009) di mana persentase insentif PPh Pasal 21 meningkat seiring dengan meningkatnya jumlah Penghasilan Kena Pajak. Penelitian Hartini tersebut menjelaskan bahwa kelompok karyawan dengan kisaran gaji tinggi yang populasinya kecil ternyata menikmati persentase manfaat insentif yang lebih tinggi dibandingkan kelompok karyawan dengan gaji rendah yang populasinya lebih besar. Artinya, insentif PPh Pasal 21 Ditanggung Pemerintah lebih berdampak terhadap karyawan dengan penghasilan yang tinggi.

Berdasarkan hasil pengujian data, insentif PPh Pasal 21 dapat diartikan kurang tepat sasaran. Hal ini dikarenakan tujuan awal kebijakan pemberian insentif PPh Pasal 21 adalah sebagai stimulus fiskal yang diharapkan dapat meningkatkan daya beli masyarakat dan menimbulkan objek PPN. Dengan adanya ketimpangan distribusi, realisasi insentif PPh Pasal 21 belum mampu mencerminkan penyerapan yang sesungguhnya. Penerima insentif yang lebih didominasi pekerja berpenghasilan tinggi mungkin memiliki pola konsumsi yang tetap dan tidak berubah sehingga tidak berdampak secara langsung terhadap objek PPN. Terlebih lagi dengan adanya pembatasan ruang gerak publik di masa pandemi Covid-19 menjadikan masyarakat enggan untuk melakukan konsumsi yang sifatnya tidak terlalu mendesak. Belanja online pun kerap menjadi pilihan demi menghindari penyebaran virus. Namun, cara belanja ini belum memiliki pengaruh signifikan terhadap laju perekonomian dikarenakan pungutan pajak online masih terus dilakukan identifikasi dan ekstensifikasi sehingga hanya ada beberapa penjual di marketplace yang telah menerapkan pungutan PPN atas transaksinya.

Alternatif lain mungkin dipilih oleh sebagian pekerja yang menerima insentif PPh Pasal 21. Dibandingkan mengambil langkah konsumtif di tengah perekonomian yang tidak menentu, masyarakat mungkin lebih memilih untuk mengalihkan manfaat insentif pajak menjadi tabungan (saving). Di masa pandemi Covid-19, animo masyarakat untuk menabung uang di bank masih cukup tinggi. Data perbankan yang menampilkan penghimpunan dana pihak ketiga (DPK) pada semester I-2020 masih tumbuh cukup tinggi secara 
tahunan (yoy), mencapai 7,95\% atau setara Rp460 triliun.

Selain itu, masyarakat cenderung memanfaatkan uang yang dimiliki untuk memenuhi kebutuhan yang sifatnya pokok saja. Sedangkan, barang kebutuhan pokok seperti beras, jagung, daging, telur, susu, buah, sayur, dan sebagainya merupakan jenis barang yang tidak termasuk dalam objek pengenaan PPN. Pengecualian barang kebutuhan pokok dari objek pengenaan PPN menjadikan adanya insentif penghasilan yang diterima oleh orang pribadi tidak akan berdampak terdampak penambahan daya beli atau konsumsi masyarakat. Dengan demikian, pemberian insentif PPh Pasal 21 tidak berpengaruh terhadap penerimaan PPN.

\subsubsection{Pengaruh Insentif PPh Pasal 22 Impor Terhadap Penerimaan PPN}

Hasil pengujian yang telah dilakukan menunjukkan bahwa insentif PPh Pasal 22 Impor berpengaruh signifikan secara positif terhadap penerimaan PPN. Hal ini sejalan dengan jurnal yang disampaikan oleh Kumar (2020) dan Padyanoor (2020) bahwa pemberian insentif fiskal berdampak terhadap peningkatan konsumsi yang dilakukan oleh masyarakat maupun badan usaha sehingga memberikan efek multiplier berupa timbulnya objek PPN pada setiap rantai konsumsi. Dengan kata lain, insentif PPh Pasal 22 Impor dapat memberikan tambahan cashflow bagi industri di Indonesia yang terdampak Covid-19.

Insentif PPh Pasal 22 Impor diwujudkan melalui pembebasan pemungutan atas impor sehingga roda impor Indonesia terus berjalan dan neraca perdagangan terjaga stabil. Selanjutnya, wajib pajak yang memanfaatkan insentif dapat menjual barang di dalam negeri dengan harga terjangkau. Dengan demikian, adanya insentif PPh Pasal 22 Impor memberikan peluang kepada wajib pajak untuk terus melakukan proses produksi. Proses produksi membutuhkan pembelian bahan baku dan penggunaan barang modal yang turut berkontribusi terhadap kenaikan penerimaan PPN. Artinya, beban atau biaya yang selama ini digunakan untuk membayar PPh Pasal 22 Impor kini dapat dialihkan untuk meningkatkan proses produksi sehingga penerimaan PPN meningkat. Berdasarkan uraian tersebut, dapat disimpulkan bahwa PPN bukan semata-mata cerminan atas konsumi melainkan juga menggambarkan proses produksi.

\subsubsection{Pengaruh Insentif PPh Pasal 25 Terhadap} Penerimaan PPN

Hasil pengujian yang telah dilakukan menunjukkan bahwa insentif PPh Pasal 25 berpengaruh signifikan secara positif terhadap penerimaan PPN. Hal ini sejalan dengan jurnal yang disampaikan oleh Kumar (2020) dan Padyanoor
(2020) bahwa kebijakan pemberian insentif PPh Pasal 25 berdampak terhadap cashflow wajib pajak badan yang selanjutnya memberikan efek multiplier berupa timbulnya objek PPN. Kondisi ini selaras dengan tujuan awal kebijakan insentif untuk membantu para wajib pajak badan yang terdampak oleh wabah virus Covid-19.

Melalui PMK Nomor 110/PMK.03/2020, pemerintah menaikkan pengurangan angsuran $\mathrm{PPh}$ Pasal 25 yang semula hanya $30 \%$ menjadi $50 \%$. Meskipun pada dasarnya insentif ini bersifat menunda, namun kesulitan cashflow yang dialami oleh wajib pajak badan dapat sedikit teratasi. Dengan demikian, wajab pajak memiliki ruang gerak yang lebih leluasa dalam mengatur cashflow demi kelangsungan usahanya.

Menurut Herman Juwono selaku Wakil Ketua Komite Tetap Pajak Kadin Indonesia sebagaimana dikutip dalam DDTC News, insentif pajak terutama insentif pengurangan angsuran PPh Pasal 25 sebesar $50 \%$ sangat bermanfaat bagi korporasi karena insentif ini paling dapat dirasakan dampaknya dalam membantu cashflow perusahaan. Aliran cashflow atas adanya insentif PPh Pasal 25 memberikan peluang kepada wajib pajak untuk mempertahankan usahanya dengan terus melakukan produksi. Proses produksi membutuhkan pembelian bahan baku dan penggunaan barang modal yang turut berkontribusi terhadap timbulnya objek PPN. Artinya, beban atau biaya setiap bulan yang selama ini digunakan untuk membayar PPh Pasal 25 kini dapat dialihkan sementara untuk meningkatkan proses produksi sehingga penerimaan PPN meningkat.

\subsubsection{Pengaruh Insentif PPh Final Berdasarkan Peraturan Pemerintah Nomor 23 Tahun 2018 Terhadap Penerimaan PPN}

Hasil pengujian yang telah dilakukan menunjukkan bahwa insentif PPh Final berdasarkan Peraturan Pemerintah Nomor 23 Tahun 2018 berpengaruh signifikan secara negatif terhadap penerimaan PPN. Penelitian yang dilakukan oleh Marlinah (2020) dan Padyanoor (2020) menyatakan bahwa pemberian insentif pajak hanya digunakan oleh UMKM untuk mampu bertahan (survive) selama masa pandemi Covid-19. Insentif bukan lagi digunakan untuk meningkatkan produksi usaha, namun lebih tepat untuk menutupi kerugian usaha akibat beban usaha yang melebihi besarnya pendapatan usaha yang diperoleh. Dampaknya, realisasi insentif pajak UMKM yang ada tidak mampu meningkatkan penerimaan PPN karena proses produksi yang justru menurun bahkan membuat banyak UMKM gulung tikar dan harus menutup usahanya.

Berdasarkan data Badan Pusat Statistik yang dikutip oleh Batara (2020), hanya ada sebagian kecil 
pelaku UMKM yang mengharapkan insentif pajak di masa pandemi Covid-19. Dibandingkan insentif, bantuan modal secara tunai lebih menarik minat para wajib pajak. Hal ini dikarenakan rendahnya permintaan barang atau jasa untuk diproduksi berdampak terhadap kesulitan cashflow bagi pengusaha UMKM. Dengan demikian, pemanfaatan insentif PPh Final UMKM menjadi kurang tepat sasaran terhadap penerimaan PPN.

Sementara itu, kini sebagian UMKM memilih beralih ke perdagangan e-commerce untuk bertahan hidup. Berdasarkan data dari Kementerian Koperasi dan UMKM yang dikutip oleh Batara (2020), sebanyak $13 \%$ atau 8 juta dari total pelaku UMKM telah beralih ke bisnis online dan sisanya sebanyak $87 \%$ masih bertahan dengan cara yang konvensional. Penjualan secara online merupakan wujud inovasi dari produk yang ditawarkan akibat adanya pembatasan ruang gerak publik dari pemerintah sehingga masyarakat melakukan aktivitas di rumah demi menghambat penyebaran virus. Akibatnya, peningkatan daya beli masyarakat teralihkan sebagian ke transasksi $e$ commerce. Pemberlakuan pemungutan PPN atas transaksi e-commerce yang baru diterapkan oleh sebagian penjual di marketplace menimbulkan dampak terhadap penerimaan PPN.

Selain itu, alasan lain yang menyebabkan insentif PPh Final UMKM justru menurunkan penerimaan PPN adalah kondisi di mana insentif ini hanya memunculkan pelaku UMKM baru yang kurang memiliki kesadaran dalam membayar pajak. Dtinjau dari ukuran usaha UMKM, wajib pajak baru yang berpotensi menimbulkan efek multiplier terhadap penerimaan PPN lebih berfokus pada kelompok pelaku usaha kecil dan pelaku usaha menengah. Kedua kelompok ini hanya menyumbang satu hingga dua persen dari total pelaku UMKM. Sedangkan, pelaku usaha mikro yang jumlahnya lebih dominan cenderung memanfaatkan insentif pajak untuk melakukan produksi yang jumlahnya kecil dan tidak berkesinambungan. Dampaknya, lingkup objek pengenaan PPN menjadi lebih sempit sehingga biaya insentif pajak yang dikeluarkan oleh pemerintah tidak sebanding dengan pengaruhnya terhadap penerimaan PPN. Dengan demikian, realisasi insentif PPh Final UMKM berbanding terbalik dengan penerimaan PPN di mana adanya realisasi insentif PPh Final justru menurunkan penerimaan PPN.

\subsubsection{Pengaruh Insentif PPN Terhadap Penerimaan PPN}

Hasil pengujian yang telah dilakukan menunjukkan bahwa insentif PPN tidak berpengaruh signifikan terhadap penerimaan PPN. Pemerintah memberikan stimulus fiskal berupa insentif PPN melalui restitusi PPN dipercepat atau pengembalian pendahuluan kepada para eksportir tanpa batasan nilai restitusi dan kepada non eksportir dengan batasan nilai restitusi paling banyak sebesar Rp5 miliar. Kemudahan restitusi PPN yang diberikan oleh pemerintah ternyata tidak serta merta berdampak terhadap likuiditas wajib pajak. Hal ini dikarenakan batasan nilai restitusi yang tinggi ternyata hanya diberikan kepada wajib pajak Klasifikasi Lapangan Usaha (KLU) tertentu saja. Padahal, restitusi PPN dipercepat sebenarnya perlu dibebaskan kepada seluruh sektor mengingat dampak wabah Covid-19 telah merambah semua jenis usaha khususnya perdagangan dan jasa. Pemberian insentif PPN yang tidak merata menyebabkan kebijakan ini kurang efektif terutama dalam memberikan efek multiplier terhadap penerimaan PPN.

Data yang disampaikan oleh Direktur Eksekutif Center for Indonesia Taxation Analysis (CITA), Yustinus Prastowo, menunjukkan bahwa realisasi restitusi dipercepat tahun lalu tanpa adanya virus Covid-19 mencapai Rp32 triliun. Dengan adanya Covid-19, realisasi restitusi akan semakin melebar dari proyeksi yang telah ditetapkan pemerintah. Data ini berusaha menjelaskan bahwa pemberian insentif PPN yang dilakukan oleh pemerintah belum mampu mengoptimalkan cashflow wajib pajak yang digunakan untuk meningkatkan produksi. Dampaknya, kegiatan produksi yang stagnan tidak mampu memengaruhi timbulnya objek pengenaan PPN sehingga insentif PPN tidak berpengaruh terhadap penerimaan PPN.

\section{SIMPULAN}

Dari kelima jenis insentif pajak yang diberikan pemerintah, ada dua jenis insentif yang berpengaruh signifikan secara positif terhadap penerimaan PPN yaitu insentif PPh Pasal 22 Impor dan insentif PPh Pasal 25. insentif PPh Pasal 22 Impor memberikan peluang kepada wajib pajak untuk terus melakukan proses produksi berupa pembelian bahan baku dan penggunaan barang modal yang turut berkontribusi terhadap kenaikan penerimaan PPN. Sama halnya dengan dengan insentif PPh Pasal 22 Impor, pemberian insentif PPh Pasal 25 berdampak terhadap cashflow wajib pajak Badan yang selanjutnya memberikan efek multiplier berupa timbulnya objek pengenaan PPN.

Sedangkan, insentif PPh Final berdasarkan Peraturan Pemerintah Nomor 23 Tahun 2018 berupa pajak Ditanggung Pemerintah berpengaruh signifikan secara negatif terhadap penerimaan PPN. Hal ini dikarenakan pemberian insentif PPh final UMKM bukan lagi digunakan untuk meningkatkan produksi usaha, melainkan untuk menutupi kerugian usaha akibat beban usaha yang tidak dapat tertutupi oleh pendapatan usaha yang diperoleh sehingga kenaikan realisasi insentif UMKM justru menyebabkan penurunan penerimaan PPN. Selain itu, insentif ini 
memunculkan adanya wajib pajak baru yang lebih didominasi oleh pelaku usaha mikro di mana kelompok mikro ini cenderung hanya mempertahankan usaha dengan tingkat produksi yang kecil sehingga menyebabkan lingkup objek pengenaan PPN menjadi lebih sempit dan menurunkan penerimaan PPN.

Insentif PPh Pasal 21 dan insentif PPN tidak berpengaruh signifikan terhadap penerimaan PPN. Realisasi penyerapan insentif PPh Pasal 21 lebih didominasi oleh pekerja dengan kisaran gaji yang tinggi di mana kelompok pekerja ini cenderung memanfaatkan insentif untuk menabung sehingga memiliki pola konsumsi yang tetap dan tidak menimbulkan efek multiplier terhadap objek pengenaan PPN. Sedangkan, realisasi penyerapan insentif PPN dengan batasan nilai yang tinggi hanya dapat dimanfaatkan oleh sekelompok wajib pajak saja sehingga kurang efektif dalam memberikan efek multiplier terhadap penerimaan PPN.

\section{IMPLIKASI DAN KETERBATASAN}

Berdasarkan hasil pengujian, insentif pajak yang telah diberikan rupanya belum sepenuhnya berdampak terhadap perekonomian, khususnya dalam mendongkrak daya beli masyarakat untuk melakukan konsumsi. Direktorat Jenderal Pajak perlu melakukan evaluasi atas pelaksanaan kebijakan pemberian insentif pajak khususnya di masa pandemi Covid-19, misalnya dengan menganalisis melalui perbandingan cashflow wajib pajak sebelum dan setelah diberikan insentif. Selain itu, pemerintah melalui Kementerian Keuangan perlu lebih fokus terhadap insentif pajak apa saja yang harus dioptimalkan penyerapannya. Terkait implikasi dalam penelitian, penulis berharap penelitian selanjutnya dapat meliputi seluruh jenis insentif pajak yang diberikan oleh pemerintah di masa pandemi. Selain itu, jangka waktu dan lingkup objek penelitian perlu diperluas untuk memperoleh hasil penelitian yang lebih mendalam.

Dalam melakukan penelitian, penulis memiliki keterbatasan data berupa objek dan waktu penelitian serta variabel insentif pajak yang digunakan. Penelitian ini juga mengabaikan penerimaan PPN yang tidak sepenuhnya dapat menggambarkan tingkat konsumsi atau produksi wajib pajak dikarenakan ada jenis konsumsi tertentu seperti konsumsi kesehatan dan pendidikan yang tidak menimbulkan objek pengenaan PPN. Selain itu, konsumsi atas barang kebutuhan pokok juga tidak termasuk objek PPN.

\section{DAFTAR PUSTAKA}

Agusti, R.R dan M. Maulinarhadi. R. (2019). E-Journal Media Bina IImiah, 14(3), 2223-2234.
Akbar, C. (2 Februari 2021). Dorong Daya Beli, Sri Mulyani Lanjutkan Sejumlah Insentif Pajak pada 2021. Diakses pada 20 Maret 2021, dari

https://bisnis.tempo.co/read/1429026/dor ong-daya-beli-sri-mulyani-lanjutkansejumlah-insentif-pajak-pada2021?page num $=1$

Arikunto. (2006). Metode Penelitian Kualitatif. Bumi Aksara.

Badan Pusat Statistik. (5 Februari 2020). Ekonomi Indonesia 2019 Tumbuh 5,02 Persen. Diakses pada 2 Januari 2021, dari https://www.bps.go.id/pressrelease/2020/ 02/05/1755/ekonomi-indonesia.html

Bakara, R.H. (7 November 2020). 3 Alasan Kenapa Insentif Pajak UMKM Kurang Laku. Diakses pada 5 Januari 2021, dari https://news.ddtc.co.id/3-alasan-kenapainsentif-pajak-umkm-kurang-laku-25348

BBC News Indonesia. (3 Maret 2020). Virus Corona: Dampaknya 'Lebih Buruk Daripada Krisis Finansial 2008' dan Pertumbuhan Ekonomi Dunia Bisa Tinggal Separuh. Diakses pada 20 Maret 2021, dari https://www.bbc.com/indonesia/dunia51720514

Darussalam. (26 September 2020). Peran Pajak sebagai Penyelamat Dampak Covid-19. Diakses pada 3 Januari 2021, dari https://news.ddtc.co.id/peran-pajaksebagai-penyelamat-dampak-covid-1924258

Dewi, I.A.S. (2019). Pengaruh Insentif Pajak PPh Badan terhadap Kenaikan Dunia Usaha dan Investasi. Diakses pada 20 Maret 2021, dari https://www.pajakku.com/read/5da003d5b 01c4b456747b71a/Pengaruh-Insentif-

Pajak-PPh-Badan-terhadap-Kenaikan-DuniaUsaha-dan-Investasi

Direktorat Jenderal Pajak. (16 Juli 2020). Kinerja Kanwil DJP Jawa Tengah I Semester I 2020. Diakses pada 10 Desember 2020, dari https://www.pajak.go.id/id/siaranpers/kinerja-kanwil-djp-jawa-tengah-isemester-i-2020

Dumairy. (2006). Perekonomian Indonesia. Erlangga.

Fitriani, F.F. (5 Mei 2020). Corona Bikin Daya Beli Loyo, Konsumsi Rumah Tangga Cuma Tumbuh 2,8 Persen. Diakses pada 20 Maret 2021, dari https://ekonomi.bisnis.com/read/2020050 5/9/1236597/corona-bikin-daya-beli-loyokonsumsi-rumah-tangga-cuma-tumbuh-28persen

Ghozali, Imam. (2005). Aplikasi Analisis Multivariate dengan Program SPSS Edisi Ketiga. Badan 
Penerbit Universitas Diponegoro.

Ghozali, Imam. (2011). Aplikasi Analisis Multivariate Dengan Program SPSS. Badan Penerbit Universitas Diponegoro.

Ghozali, Imam. (2016). Aplikasi Analisis Multivariete Dengan Program IBM SPSS 23 (Edisi 8) Cetakan ke VIII. Badan Penerbit Universitas Diponegoro.

Greene, W. H. (1997). Econometric Analysis. PrenticeHall International.

Gujarati, D.N. dan D.C. Porter. (2009). Basic Econometrics 5th ed. McGraw-Hill.

Gunadi. (2013). Panduan Komprehensif Pajak Penghasilan. Bee Media Indonesia.

Hartini. (2009). Analisis Manfaat Penurunan Tarif Pajak Penghasilan Orang Pribadi PPh Pasal 21 dan Insentif PPh Pasal 21 Ditanggung Pemerintah Tahun 2009 Bagi Wajib Pajak. (Tesis, Universitas Diponegoro, 2009). Diakses dari https://core.ac.uk/download/pdf/1172358 8.pdf

Herman. (2007). Pengaruh Pertumbuhan Ekonomi terhadap Penerimaan Pajak Penghasilan dan Pajak Pertambahan Nilai. Media Riset Akuntansi, Auditing, dan Informasi, 7(1), 83105.

Hutagaol, John. (2007). Perpajakan Isu-isu Kontemporer. Graha IImu.

Irawan, T.T. (2016). Dampak Insentif Pajak Perumahan terhadap Potensi Penerimaan Pajak Negara dan Peningkatan Pendapatan Masyarakat (Kasus Provinsi Papua). Jurnal Riset Manajemen dan Bisnis, 1(1), 13-22.

Kumar, J. dan I. Aribowo. (2020). Insentif dan Disinsentif Fiskal dalam Upaya Pencapaian Target Penerimaan Pajak Tahun 2020. Indonesian Tax Journal, 4(2), 14-20.

Mardani, R. (2020). Uji Asumsi Klasik untuk Regresi Data Panel. Diakses pada 31 Desember 2020, dari https://mjurnal.com/skripsi/ujiasumsi-klasik-untuk-regresi-data-panel/

Mardiasmo. (2016). Perpajakan Edisi Revisi Tahun 2016. Penerbit Andi.

Marlinah, L. (2020). Memanfaatkan Insentif Pajak UMKM dalam Upaya Mendorong Pemulihan Ekonomi Nasional. Jurnal IKRA-ITH Ekonomika, 4(2), 73-38.

Masyitah, E. (2019). Faktor-Faktor yang Memengaruhi Penerimaan PPN dan PPnBM. Accumulated Journal (Accounting and Management Research Edition), 1(2): 89104.

OECD. (2016). Revenue Statistics 2016: Tax Revenue Trends in the OECD. Diakses dari www.oecd.org/tax/tax-policy/revenuestatistics.htm
Olivia, G. (4 Maret 2020). CITA: Kemenkeu Perlu Pertimbangkan Insentif PPN dan Tarif Pajak UMKM. Diakses pada 5 Januari 2021, dari https://nasional.kontan.co.id/news/citakemenkeu-perlu-pertimbangkan-insentifppn-dan-tarif-pajak-umk

Padyanoor, A. (2020). Kebijakan Pajak Indonesia Menanggapi Krisis COVID-19: Manfaat bagi Wajib Pajak. E-Jurnal Akuntansi, 30(9), 22162230.

Pakasi, A. (10 April 2020). IMF Proyeksikan Ekonomi Dunia Terburuk Sejak Great Depression; Indonesia Perkecualian?. Diakses pada 20 Desember 2020, dari https://www.vibiznews.com/2020/04/10/i mf-proyeksikan-ekonomi-dunia-terburuksejak-great-depression-indonesiaperkecualian/

Pakpahan, A.K. (2020). COVID-19 dan Implikasi Bagi Usaha Mikro, Kecil, dan Menengah. Universitas Katolik Parahyangan.

Peraturan Menteri Keuangan Nomor 110/PMK.03/2020. Insentif Pajak untuk Wajib Pajak Terdampak Pandemi Corona Virus Disease 2019. 14 Agustus 2020. Berita Negara Republik Indonesia Tahun 2020 Nomor 918. Jakarta.

Priharto, S. (14 November 2018). Kebijakan Fiskal: Pengertian, Tujuan, Jenis, dan Komponennya. Diakses pada 20 Maret 2021, dari

https://cpssoft.com/blog/keuangan/kebijak an-fiskal-pengertian-lengkap/

Saepudin. (2008). Analisis Faktor-Faktor yang Memengaruhi Pajak Pertambahan Nilai (PPN) di Sumatera Utara. Jurnal Perpajakan Indonesia, 1(6):36-38.

Tugino. (2012). Analisis Faktor-Faktor yang Memengaruhi Pajak Pertambahan Nilai di Indonesia. (Tesis, Universitas Sumatra Utara, 2012). Diakses dari http://repository.usu.ac.id/handle/1234567 89/51143

Trepelkov, Alexander, H. Tonino, dan D. Halka. Penyunting. (2017). United Nations Handbook on Selected Issues in Protecting the Tax Base of Developing Countries Second Edition. Diakses dari http://www.un.org/esa/ffd/publications/ha ndbook-tax-base-second-edition.html

Undang-Undang Republik Indonesia Nomor 42 Tahun 2009. Pajak Pertambahan Nilai Barang dan Jasa dan Pajak Penjualan atas Barang Mewah. 15 Oktober 2009. Lembaran Negara Republik Indonesia Tahun 2009 Nomor 150. Jakarta.

Utami, R.K. (2010). Insentif Pajak Penghasilan Pasal 
21 sebagai Salah Satu Kebijakan Pemerintah. (Skripsi, Universitas Airlangga, 2010).

Diakses

dari

http://repository.unair.ac.id/14097/

Velaj, E dan L. Prendi. (2014). Tax Revenue - The
Determinant Factors-The Case of Albania. European Scientific Journal, 28(1), 27-35.

Waluyo. (2013). Perpajakan Indonesia. Salemba Empat. 